\title{
24. CHEMISTRY OF HALITE AND POTASH SALT CORES, DSDP SITES 374 AND 376, LEG 42A, MEDITERRANEAN SEA
}

\author{
Robert Kuehn, Kaliforschung-Institut, Hannover, Germany \\ and \\ Kenneth J. Hsü, Geologisches Institut, ETH, Zürich, Switzerland
}

\begin{abstract}
Two salt cores from Site 376 and two from Site 374 were analyzed. The salt core from Site 376 consists mainly of halite, which is associated with gypsum. The low bromine content of the halite $(20-30 \mathrm{ppm})$ suggests a derivation through recycling.

Sample 22-3, 24-30 cm from Site 374 contains halite in association with polyhalite, sulfoborite, sylvite, bischofite, and clay minerals. The bromine content in halite ranges from 114 to 218 $\mathrm{ppm}$. The halite was precipitated with polyhalite from an evaporated seawater. The somewhat lower than standard bromine content in some cores suggests some contamination of the seawater by waters from continental sources.

Sample 22-3, 107-130 cm from Site 374 contains halite in association with polyhalite and kainite. The average bromine content in halite is $320 \mathrm{ppm}$ and in kainite is $830 \mathrm{ppm}$. The values are comparable to those obtained from analyses of salts in Sicily and in Calabria, and they suggest primary precipitation from evaporated seawater.

The bromine profiles of both Site 374 cores show very abrupt changes. The pattern is consistent with our postulate, on the basis of our interpretation of the immediately overlying sediments, that the brine lake was not very deep when the halite and potash salts were deposited at Site 374.
\end{abstract}

\section{INTRODUCTION}

Halite was cored during the first deep-sea drilling cruise to the Mediterranean Sea (DSDP Leg 13), but more soluble salts were not positively identified. That we missed them during the earlier cruise is not surprising because we did not drill in the middle of abyssal plains. Hole 124, from which halite was recovered, was located on the eastern edge of the Balearic Abyssal Plain. The data from Leg 13, however, permitted us to recognize a "bull's eye" zonation of saline minerals in accordance with the desiccated deep-basin model of Hsü et al, (1972). Maria Cita and W. B. F. Ryan, members of the JOIDES Mediterranean Advisory Panel, proposed that during Leg $42 \mathrm{~A}$ we hit the center of the "bull's eye" by drilling in the center of the abyssal plains where potash salts should have been precipitated from the last bitterns. The prediction was fully borne out by drilling. We recovered cores of potash salts in addition to halite, at Site 374 in the center of the Ionian Basin of halite, but with no potash salts, from Hole 376 on the flank of the Antalya basin.

Cores of potash salts (Hole 374) and halite (Holes 374 and 376) were analyzed at the KaliforschungsInstitut. In this paper we summarize the chemistry and mineralogy of the salts and discuss their origin and their environments of deposition.

\section{ANALYTICAL METHODS}

The analytical methods for determination of the elements are as follows:

\footnotetext{
$\mathrm{Mg}+\mathrm{Ca}$ titration together with Idranal (= Komplexon) and Eriochrom-black as indicator

$\mathrm{Ca}$ titration as for $\mathrm{Mg}+\mathrm{Ca}$, but with Calconcarbonacid as indicator

$\mathrm{Mg}$ by calculation, $(\mathrm{Mg}+\mathrm{Ca})-\mathrm{Ca}=\mathrm{Mg}$

$\mathrm{Na}$ and $\mathrm{K}$ with flame photometer (system Eppendorf)

$\mathrm{Sr}$ and $\mathrm{Rb}$ by atomic absorption (Atom-Absorption-Spectral photometer, Model 448 of Beckman)

$\mathrm{SO}_{4} \quad$ gravimetric as $\mathrm{BaSO}_{4}$

$\mathrm{Cl}$ titration according to $\mathrm{Mohr}$ (with $\mathrm{AgNO}_{3}$ )

$\mathrm{Br} \quad$ according to method of van der Meulen, but essentially improved by D'Ans and Höfer (1934) (see Kuehn and Hsü, 1974 for details)

$\mathrm{H}_{2} \mathrm{O}$ loss of ignition, but also taking into account the loss of $\mathrm{HCl}$ (reaction of $\mathrm{H}_{2} \mathrm{O}$ with $\mathrm{Cl}$ from certain salts); making a Cl-determination before and after this procedure (see Küehn and Ritter, 1958, for details).
} 
Salt minerals were identified by petrographic microscope. Oil-immersion methods of measuring refractive indices were used for the identification of the very minute amount of sulfoborite in Sample 374-22-3, 24$34 \mathrm{~cm}$.

\section{ANALYTICAL RESULTS}

Four samples were analyzed. The samples were obtained from the "working half" of cores which had been split longitudinally. The "working half" specimen was consumed by analysis; the other half is preserved in the DSDP archive collection.

Each of the core samples was subdivided into several samples, numbered 1-19, inclusive. In addition, the cuttings from each core were gathered to make a "saw-cutting" sample. The analysis of the "sawcutting" sample gives an average composition of the entire core sample.

Following petrographic determination of the mineralogy for each sample, quantitative chemical data were obtained. The distribution of bromine in the various salts of cores from Hole 374 was determined by two different methods as described below.

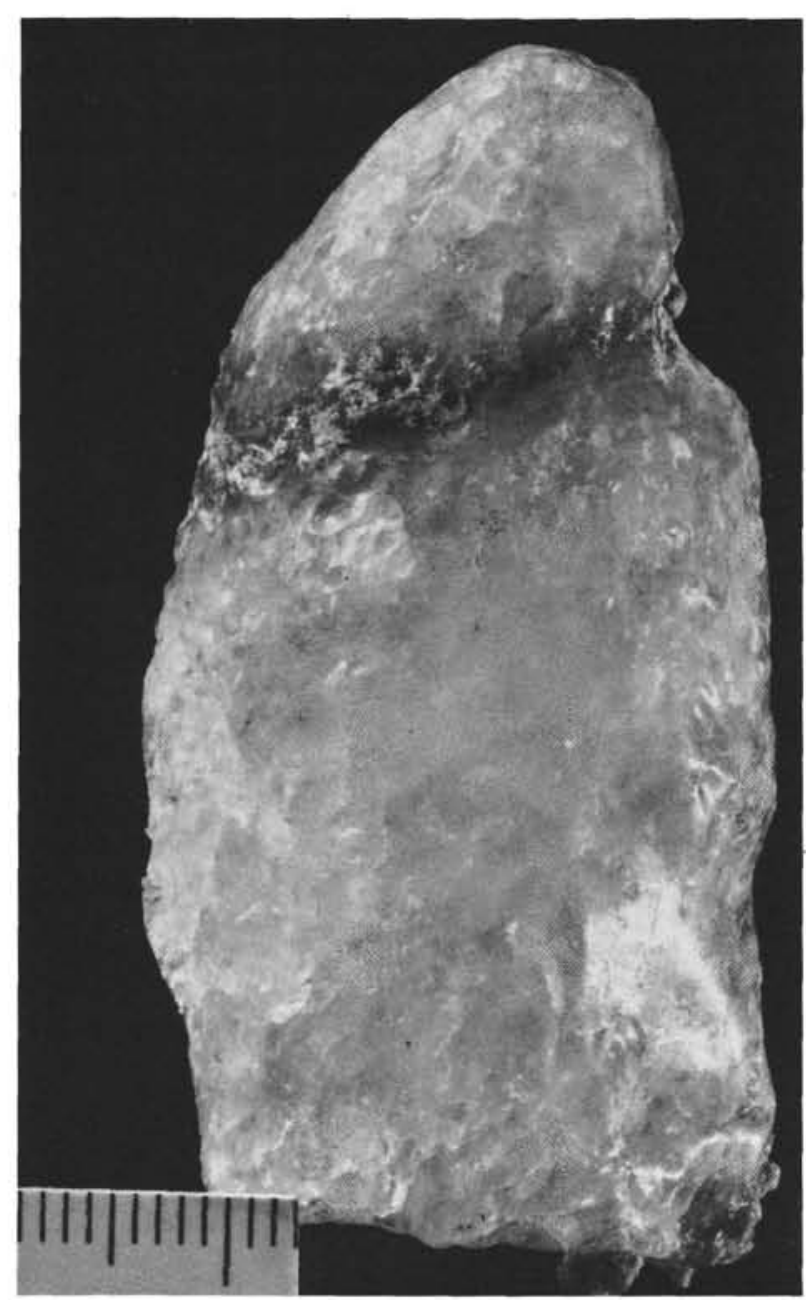

IA

\section{Sample 376-22-1, 40-44 cm}

This core segment was $4 \mathrm{~cm}$ long and $2.5 \mathrm{~cm}$ in diameter and consisted of transparent halite crystals. It comprised one-half of a longitudinally split core. The half core was divided again (perpendicular to the core axis) to provide material for two analyses. The specimen on the upper rounded end is sample 1; the lower specimen with the flat end is sample 2 (Figure 1). The results of the chemical analyses in percent weight is shown by Table 1 .

\section{Section 376-23-1}

This sample, diameter $1.5 \mathrm{~cm}$, was broken into three samples, Samples 3, 18, 19. Sample 3 is a 1-cm-thick halite detached from sample 18. The halite is impure and mottled gray. The remainder of sample 18 is a grayish gypsum with clay minerals. Sample 19 was broken off samples 3 and 18 during transport; it is also gypsum with halite and clay minerals. The results of the chemical analysis of the three samples are shown in Tables 1 and 2 .

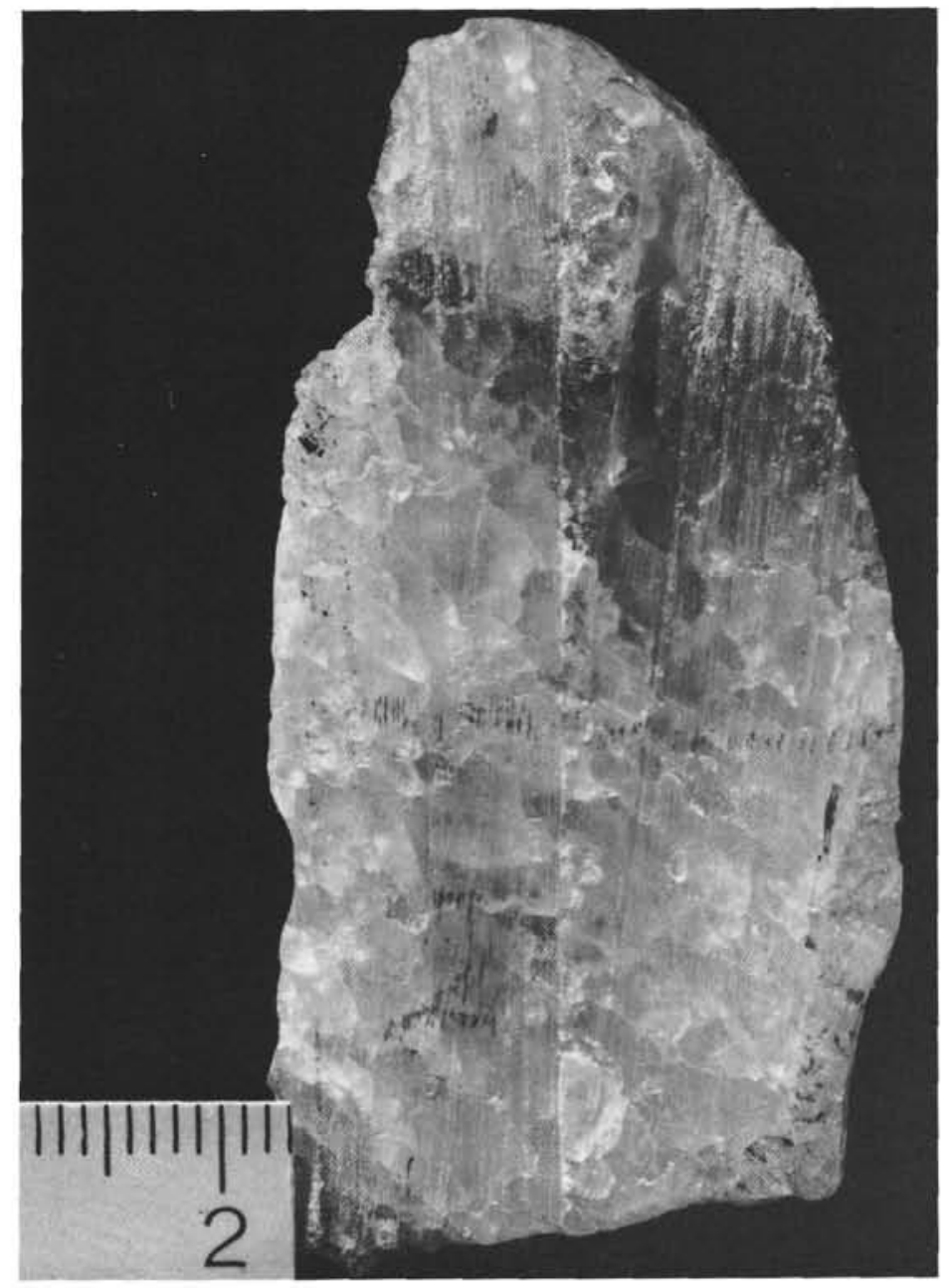

1B

Figure 1. Halite core from Sample 376-22-1, 40-44 cm. (A) outer surface; (B) section. 
The bromine content of sample 18 corresponds to a value of 0.003 weight by percent bromine in pure halite.

The strontium, contained in the gypsum only, is $0.10 \%$ (or $1000 \mathrm{ppm}$ ) in sample 18 and $0.15 \%(=1500$ ppm) in sample 19.

\section{Sample 374-22-3, 24-34 cm}

This specimen was $14 \mathrm{~cm}$ long and $2.7-2.9 \mathrm{~cm}$ in diameter. It consisted of gray to dark gray irregularly and finely stratified, halite with somewhat inclined bedding (Figure 2). Polyhalite seams stand out as riblike prominences which formed as a result of the differential corrosion during the coring operation. The core has somewhat irregular halite laminations which are only a few millimeters thick; only one pure halite laminae exceeds $0.5 \mathrm{~cm}$. After the core was split longitudinally, the working half of the core was divided into nine samples of about equal size $(1.5 \mathrm{~cm}$ thick). The samples were numbered from 4 to 12 . The microscopic investigation of the saw-cuttings showed that the core consists mainly of halite with some polyhalite, $\mathrm{K}_{2} \mathrm{MgCa}_{2}\left(\mathrm{SO}_{4}\right)_{4} \cdot 2 \mathrm{H}_{2} \mathrm{O}$, and traces of sulfoborite, $\mathrm{MgF}_{2} \cdot 2 \mathrm{MgSO}_{4} \cdot 3 \mathrm{Mg}(\mathrm{OH})_{2} \cdot 4 \mathrm{~B}(\mathrm{OH})_{3}$. The "saw-cutting" sample was analyzed for $\mathrm{K}_{2} \mathrm{O}, \mathrm{MgO}$, $\mathrm{CaO}, \mathrm{Cl}, \mathrm{SO}_{3}$, and insolubles in $\mathrm{HNO}_{3}$. The results, in percent weight, are as follows:

$\begin{array}{lr}\mathrm{K}_{2} \mathrm{O} & 1.16 \\ \mathrm{MgO} & 1.33 \\ \mathrm{CaO} & 1.33 \\ \mathrm{Cl} & 54.82 \\ \mathrm{SO}_{3} & 3.84 \\ \mathrm{HNO}_{3} \text {-insoluble } & 0.58\end{array}$

An additional $\mathrm{MgCl}_{2}$ determination, by the $\mathrm{C}_{2} \mathrm{H}_{5}(\mathrm{OH})$ extraction method, gives $\mathrm{MgCl}_{2} 0.78 \%$ by weight. The boron content is very small, and was detected by complexing boron to form boric acid methyester.

The distribution of the elements among the petrographically identified phases are calculated and shown in Table 3. To round out the computations, we assumed the presence of sylvite and bischofite $\left(\mathrm{MgCl}_{2}\right.$ $6 \mathrm{H}_{2} \mathrm{O}$ ), which were not identified petrographically. The calculation indicated that a slight surplus of $\mathrm{MgO}$ $(0.47 \%)$ was present. This could have been derived from the dissolution of clay or is possibly a result of accumulated analytical errors. The analysis of the extract with $\mathrm{C}_{2} \mathrm{H}_{5}(\mathrm{OH})$ gives in percent weight:

$$
\begin{array}{ll}
\mathrm{NaCl} & 2.26 \\
\mathrm{MgCl}_{2} & 0.78 \\
\mathrm{Br} & 0.0116
\end{array}
$$

In evaluating the analysis above we assume that the $\mathrm{MgCl}_{2}$ constitutes $1.66 \%$ of the bischofite. An additional $0.0135 \%$ bromine was found in the residue of this alcoholic extraction. According to this, the original "saw-cutting", sample contained $0.0116+0.0135=$
TABLE 1 Chemical Analyses of Halite From Site 376 (Wt \%)

\begin{tabular}{ccccc}
\hline Specimen & $\mathrm{KCl}$ & $\mathrm{NaCl}$ & $\mathrm{Br}$ & $\mathrm{Br}$ per $100 \mathrm{NaCl}$ \\
\hline 1 & & 98.43 & 0.0021 & 0.0021 \\
2 & & 98.61 & 0.0020 & 0.0020 \\
3 & 0.04 & 98.39 & 0.0024 & 0.0024 \\
\hline
\end{tabular}

TABLE 2

Chemical Analyses of Gypsum and Halite From Site 376 (Wt \%)

\begin{tabular}{ccccccccc}
\hline \multirow{2}{*}{ Specimen } & $\mathrm{Ca}$ & $\mathrm{Sr}$ & $\mathrm{Br}$ & Halite & $\mathrm{Gypsum}$ & $\mathrm{MgCl}_{2}$ & $\mathrm{CaCl}_{2}$ & \multicolumn{1}{c}{$\mathrm{Ca}$} \\
\hline 18 & 12.34 & 0.053 & 0.0018 & 47.01 & 52.86 & 0.66 & 0.09 & 4.3 \\
19 & 20.82 & 0.14 & n.d. & 10.50 & 89.03 & 0.52 & 0.25 & 6.7 \\
\hline
\end{tabular}

$0.0251 \%$ bromine. Assuming that the bromine content in the halite is $\mathrm{X}$, in the sylvite it is $10 \mathrm{X}$, and in the bischofite it is $\mathrm{Y}$, we have

$$
\begin{gathered}
89.35 \mathrm{X}+0.06 \times 10 \mathrm{X}+1.66 \mathrm{Y}=100 \times 0.0251 \\
2.26 \mathrm{X}+1.66 \mathrm{Y}=100 \times 0.0116
\end{gathered}
$$

Solving the equations, we obtain

$$
\mathrm{X}=0.0154 \%, \mathrm{Y}=0.68 \% \mathrm{Br}
$$

We assume that the ratio of halite to bischofite is the same in the single specimens Samples 4-12 as in the whole core (on the basis of the analysis of the "sawcutting" samples) and that the bromine content of the bischofite is always the same. With these assumptions, we calculate the bromine contents of the single specimens shown in Table 4.

\section{Sample 374-22-3, 107-130 cm}

This specimen is $14.3 \mathrm{~cm}$ long and $4 \mathrm{~cm}$ in diameter. It has a strongly corroded or washed surface (Figure 3 ). The salt is dark gray with some greenish tint and is rather dense. An indistinct layering is present and shows a very steep dip of about $70^{\circ}$.

The core segment was split longitudinally and the working half was divided into 5 samples, numbered 13-17. The analysis of the "saw-cutting" sample gives an average composition of the entire sample (all in percent by weight) as follows:

$\begin{array}{lc}\mathrm{K}_{2} \mathrm{O} & 12.91 \\ \mathrm{MgO} & 10.53 \\ \mathrm{CaO} & 0.99 \\ \mathrm{SO}_{3} & 23.04 \\ \mathrm{Cl} & 28.37 \\ \text { insoluble } & 0.57 \\ \mathrm{Br} & 0.0622 \\ \mathrm{Rb} & 0.0051\end{array}$

Kainite, polyhalite, and halite were identified petrographically. The analytic determinations (percent by weight) yielded 


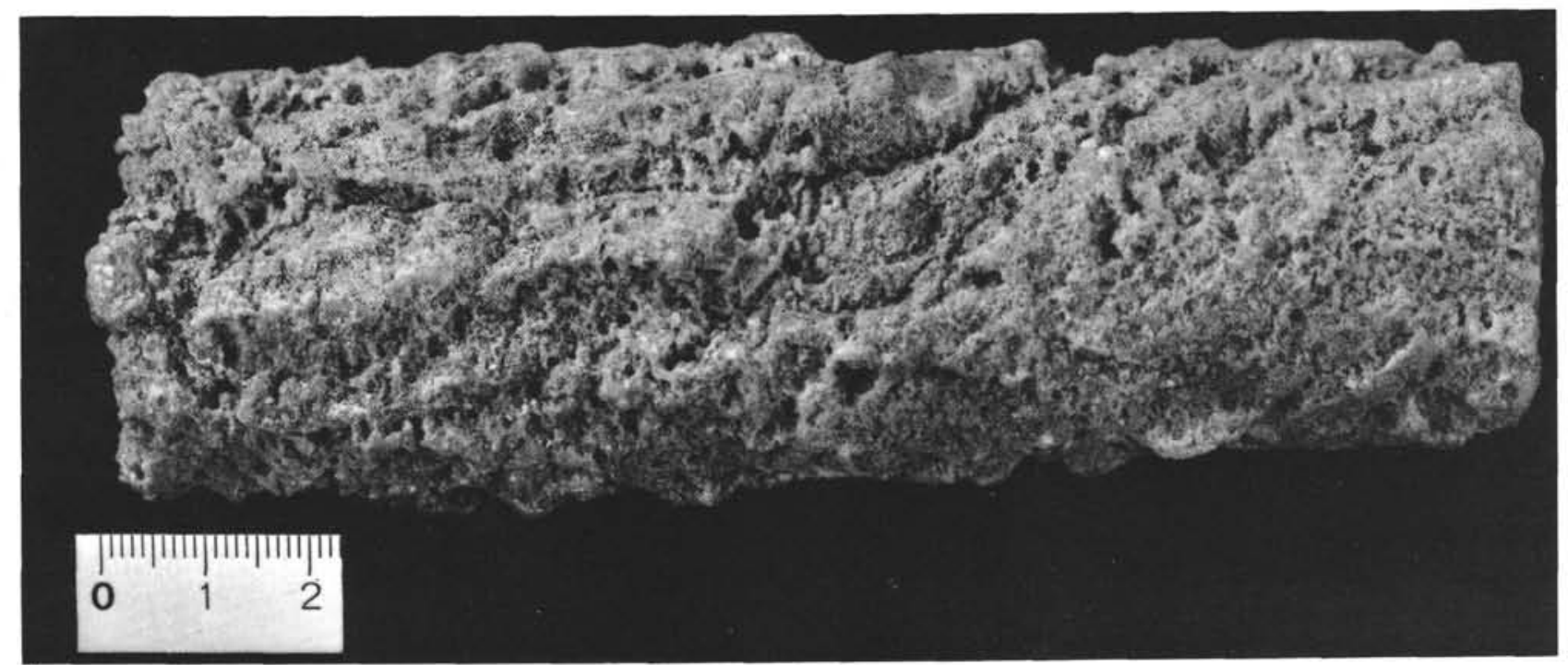

A

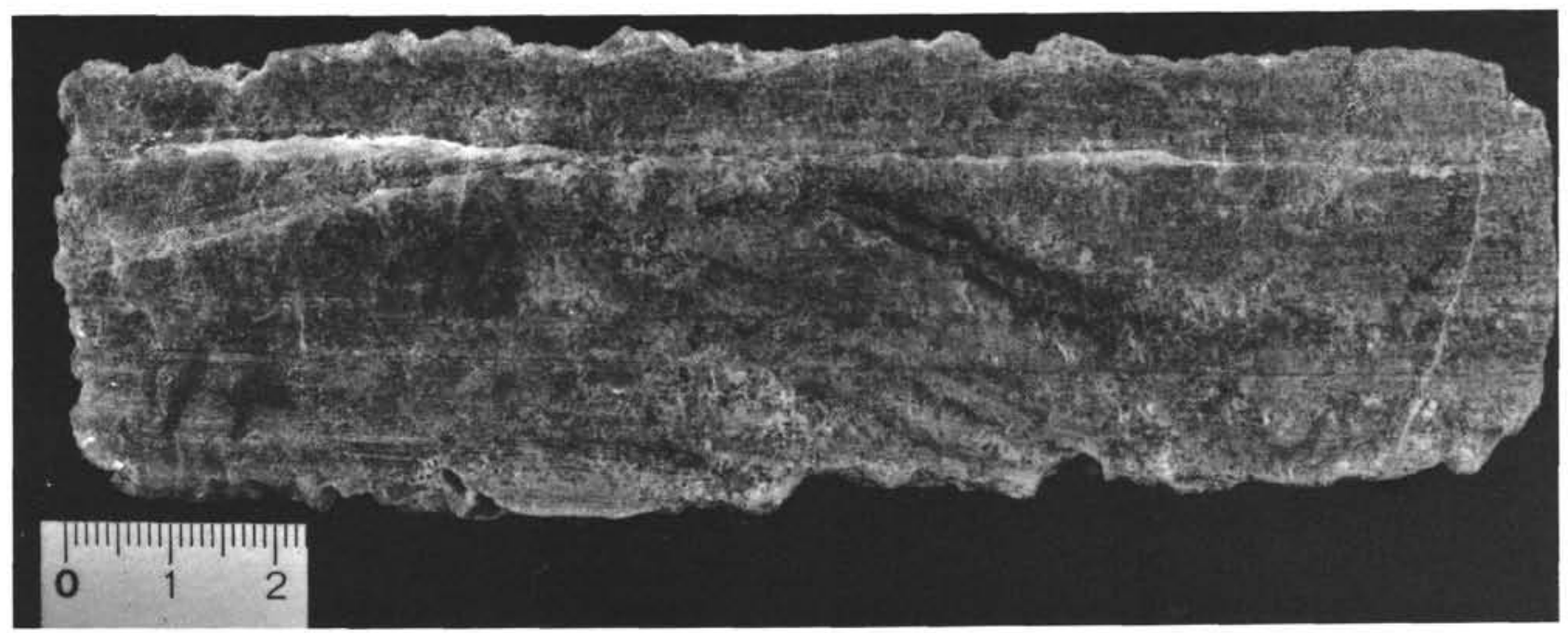

B

Figure 2. Halite associated with polyhalite and other potash salts, Sample 374-22-3, 24-30 cm. (A) outer surface; (B) section.

$\begin{array}{lr}\text { kainite } & 62.60 \\ \text { polyhalite } & 5.31 \\ \text { halite } & 31.80 \\ \text { insoluble } & 0.57\end{array}$

The rubidium contents of polyhalite are mostly low. The primary polyhalite from Stassfurt has, for example $<0.0001 \%$ Rb (Kuehn, 1972).

Assuming, as a first approximation, a rubidium content of $0.0001 \% \mathrm{Rb}$ in the polyhalite, the rubidium content of the kainite is calculated to be 0.008 percent by weight $(62.6 \times X+5.31 \times 0.0001=100 \times 0.0051$ $\mathrm{x}=0.008)$.

The special investigation of bromine was difficult. The size fraction $0.4-1 \mathrm{~mm}$ was obtained from samples 13-17. A kainite-rich fraction and a halite (+ polyhalite)-rich fraction were separated with a heavy liquid having a density of 2.15 . Halite was then separated from the polyhalite with a heavy liquid having a density of 2.22 . The results of the analyses of kainiterich and halite-rich fractions are given in Table 5. Also shown in Table 5 are the analytical results of undifferentiated size fractions $<0.4 \mathrm{~mm}$.

In order to determine kainite and pure halite contents, we devised a special method of calculation. We plotted the analytical results in a two-phase diagram with the percentages of kainite and halite on the abscissa and percentage of bromine on the ordinate (Figure 4). Ideally, the results of the analyses of all three fractions (halite-rich, kainite-rich, and undifferentiated $<0.4 \mathrm{~mm}$ ) of one sample should lie on a straight line. Extrapolation to the intercepts with the kainite- and halite-axis gives the desired values of bromine contents for pure phases.

As shown from Figure 1, the data points plotted for samples 14, 16, and 17 constitute straight lines. However, the extrapolation gives a very high Bromine content for the halite in samples 16 and 17. The 
TABLE 3

Computed Mineral Composition of Sample $374-22-3,24-34 \mathrm{~cm}$

\begin{tabular}{|c|c|c|}
\hline & Weight (\%) & Moles and Molar Relations \\
\hline $\mathrm{K}$ & 0.96 & $0.02455=2 \times 0.01185+0.00085(=$ Polyhalite and Sylvite $)$ \\
\hline $\mathrm{Na}$ & 35.15 & $1.52896=1 \times 1.52896(=$ Halite $)$ \\
\hline $\mathrm{Mg}$ & 0.80 & $\begin{aligned} 0.03291= & \underset{ }{1} \times 0.01185+0.00823+6 \times 0.0003+0.01183 \\
& \left.\text { (= Polyhalite }+\mathrm{MgCl}_{2}+\text { Sulfoborite }+ \text { Rest } \mathrm{MgO}\right)\end{aligned}$ \\
\hline $\mathrm{Ca}$ & 0.95 & $0.02370=2 \times 0.01185(=$ Polyhalite $)$ \\
\hline $\mathrm{SO}_{4}$ & 4.61 & $0.04799=4 \times 0.01185+2 \times 0.0003$ (=Polyhalite+Sulfoborite) \\
\hline $\mathrm{Cl}$ & 54.82 & $\begin{aligned} 1.54627= & 1 \times 0.00085+2 \times 0.00823+1 \times 1.52896 \\
& \left(=\mathrm{KCl}+\mathrm{MgCl}_{2}+\mathrm{NaCl}\right)\end{aligned}$ \\
\hline $\mathrm{H}_{2} \mathrm{O}$ & 1.365 & $\begin{aligned} 0.07578= & 2 \times 0.01185+6 \times 0.00823+9 \times 0.0003 \\
& \text { (Crystal water of Poly halite, Bischofite }+ \text { Sulfoborite) }\end{aligned}$ \\
\hline $\begin{array}{l}\mathbf{B} \\
\mathbf{F}\end{array}$ & $\begin{array}{l}0.013 \\
0.011\end{array}$ & $\begin{array}{l}0.0012=4 \times 0.0003 \\
0.0006=2 \times 0.0003 \quad(=\text { Sulfoborite })\end{array}$ \\
\hline o & 0.011 & $0.01453=9 \times 0.0003+1 \times 0.01183(=$ Sulfoborite + Rest $\mathrm{MgO})$ \\
\hline Insoluble & 0.58 & and \\
\hline
\end{tabular}

Note: Weight $(\%)$ of the minerals are then: molecular weight $\times$ molar relation $=$ weight (\%)

$\begin{array}{rlr}602.93 \times 0.01185 & =\text { polyhalite } & 7.14 \\ 725.309 \times 0.0003 & =\text { sulfoborite } & 0.22 \\ 58.443 \times 1.52896 & =\text { halite } & 89.35 \\ 74.555 \times 0.0085 & =\text { sylvite } & 0.06 \\ 203.30 \times 0.00823 & =\text { bischofite } & 1.66 \\ 40.304 \times 0.01183 & =\mathrm{MgO} & 0.47 \\ & \text { insoluble } & 0.58 \\ & & 99.48\end{array}$

content is higher than all previously known values. Only the analyses of sample 14 seems to give a plausible result.

The evaluation of the analyses from samples 13 and 15 was very difficult because the three data points of
TABLE 4

Bromine Content in Halite of Sample 374-22-3, 24-34 cm. (all values are in percent by weight)

\begin{tabular}{clcccc}
\hline Specimen & $\mathrm{Cl}$ & $\mathrm{Br}$ & $\mathrm{NaCl}$ & $\mathrm{MgCl}_{2} \cdot 6 \mathrm{H}_{2} \mathrm{O}$ & $\mathrm{Br}$ per $100 \mathrm{NaCla}^{\mathrm{a}}$ \\
\hline 4 & 52.62 & 0.0286 & 85.79 & 1.58 & 0.0209 \\
5 & 54.04 & 0.0235 & 88.10 & 1.63 & 0.0141 \\
6 & 52.99 & 0.0297 & 86.39 & 1.60 & 0.0218 \\
7 & 54.175 & 0.0237 & 88.33 & 1.63 & 0.0143 \\
8 & 54.515 & 0.0251 & 88.89 & 1.66 & 0.0178 \\
9 & 52.48 & 0.0282 & 85.56 & 1.59 & 0.0203 \\
10 & 55.33 & 0.0239 & 90.23 & 1.68 & 0.0138 \\
11 & 57.01 & 0.0238 & 92.95 & 1.73 & 0.0114 \\
12 & 55.02 & 0.0245 & 89.72 & 1.67 & 0.0121 \\
\hline
\end{tabular}

aFor example, the Br-content of Specimen 4 is calculated from $85.79 \times \mathrm{X}+1.58 \times 0.68=100 \times 0.0286, \mathrm{X}=0.0209$.

each sample do not fall on a straight line. Connecting the value obtained for the kainite fraction with one of the other points (halite fraction, or $<0.4 \mathrm{~mm}$ size fraction), results in negative bromine contents in the halite. This is impossible.

We resolved the problem by assuming that the $\mathrm{Br}_{\mathrm{NaCl}}: \mathrm{Br}_{\text {kainite }}$ ratio produces a straight line connecting the data points of the halite and of the $4 \mathrm{~mm}$ size fraction. We then draw a line parallel to the data points obtained from the analysis of the kainite frac-
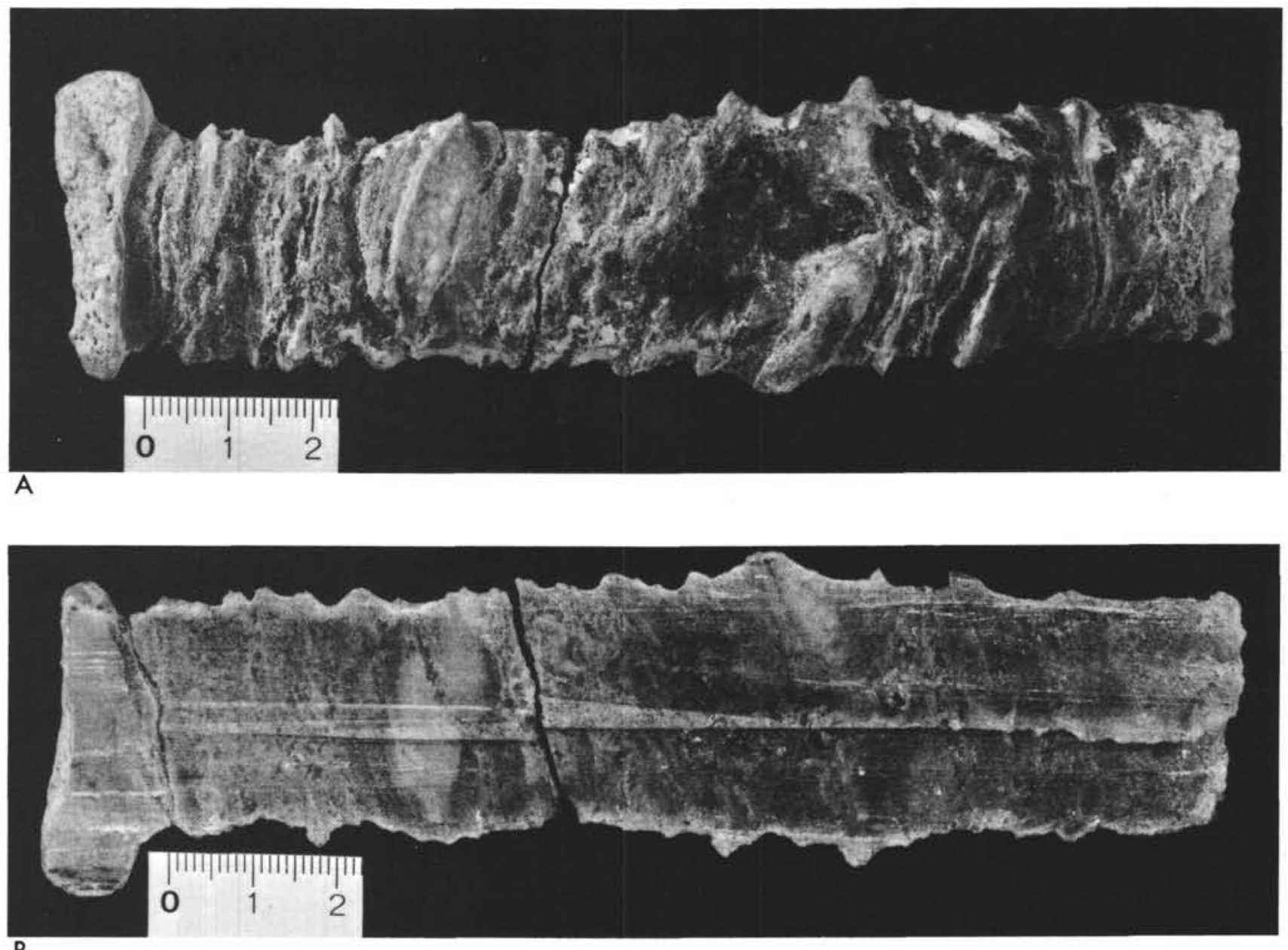

B

Figure 3. Halite associated with kainite and polyhalite, Sample $374-22-3,107-130 \mathrm{~cm}$. Clay seams stand out as prominences. (A) outer surface; $(B)$ section. 
TABLE 5

Bromine Analyses of Different Fractions of Sample 374-22-3, $107-130 \mathrm{~cm}$

\begin{tabular}{c|ccc|ccc}
\hline & \multicolumn{3}{|c|}{ Weight (\%) } & \multicolumn{2}{c}{$\begin{array}{c}\text { Calculated so that kainite } \\
+ \text { halite }=100 \text { weight }(\%) \\
\text { Specimen }\end{array}$} & \multicolumn{3}{|c|}{$\begin{array}{c}\text { Size } \\
\text { Analyzed } \\
\text { + Content }\end{array}$} & $\begin{array}{c}\text { Kainite } \\
\text { Fraction }\end{array}$ & $\begin{array}{c}\text { Fraction } \\
<0.4 \mathrm{~mm}\end{array}$ & $\begin{array}{c}\text { Halite } \\
\text { Fraction }\end{array}$ & $\begin{array}{c}\text { Kainite } \\
\text { Fraction }\end{array}$ & $\begin{array}{c}\text { Fraction } \\
<0.4 \mathrm{~mm}\end{array}$ & $\begin{array}{c}\text { Halite } \\
\text { Fraction }\end{array}$ \\
\hline Kainite & 89.98 & 65.75 & 59.06 & 91.70 & 69.84 & 63.40 \\
13 Halite & 8.14 & 28.40 & 34.09 & 8.30 & 30.16 & 36.60 \\
Bromine & 0.0761 & 0.0312 & 0.0264 & 0.0776 & 0.0331 & 0.0283 \\
\hline Kainite & 89.00 & 60.70 & 52.40 & 91.12 & 65.30 & 56.48 \\
14 Halite & 8.67 & 32.26 & 40.37 & 8.88 & 34.70 & 43.52 \\
Bromine & 0.0369 & 0.0311 & 0.0289 & 0.0378 & 0.0335 & 0.0312 \\
\hline Kainite & 89.82 & 53.61 & 46.83 & 91.52 & 58.50 & 51.45 \\
15 Halite & 8.32 & 38.03 & 44.19 & 8.48 & 41.50 & 48.55 \\
Bromine & 0.0776 & 0.0336 & 0.0322 & 0.0791 & 0.0367 & 0.0354 \\
\hline Kainite & 90.87 & 64.24 & 49.55 & 92.45 & 68.65 & 53.62 \\
16 Halite & 7.42 & 29.33 & 42.86 & 7.55 & 31.35 & 46.38 \\
Bromine & 0.0198 & 0.0295 & 0.0317 & 0.0201 & 0.0315 & 0.0343 \\
\hline Kainite & 91.65 & 70.21 & 47.29 & 92.93 & 73.73 & 51.03 \\
17 Halite & 6.97 & 25.01 & 45.38 & 7.07 & 26.27 & 48.97 \\
Bromine & 0.0200 & 0.0303 & 0.0444 & 0.0203 & 0.0318 & 0.0479 \\
\hline
\end{tabular}

tion (Figure 4), and from this line extrapolate the values for bromine in halite. The results are given in Table 6 . The results for sample 14 are the only reliable ones; the others are very questionable, especially those for samples 13 and 15 .

Taking the average value of the bromine partitioning, or $\mathrm{Br}_{\text {halite }}: \mathrm{Br}_{\text {kainite }}=1: 2.6$, and using the analytically determined bromine value of the "saw-cutting" sample, we computed the average bromine content of halite and of kainite in Sample 374-22, 107-130 cm, as follows:

$$
\begin{aligned}
& 62.6 \times 2.6 \mathrm{X}+31.8 \mathrm{X}=100 \times 0.0622 \\
& \mathrm{X}=0.032 \\
& 2.6 \mathrm{X}=0.083
\end{aligned}
$$

The result indicates that the bromine content in halite is $0.032 \%$ and $0.083 \%$ in kainite.

\section{DISCUSSION OF RESULTS}

\section{Halite From Site 376}

All four halite samples analyzed from Hole 376 have a low bromine content ranges from $20 \mathrm{ppm}$ to 30 $\mathrm{ppm}$. This bromine content is considerably less than that which occurs in the first halite precipitated from evaporated seawater. The halite is almost certainly recycled. Halite of similar origin in Units C and D in Porto Empedocle, Sicily also has a low bromine content of about $10 \mathrm{ppm}$ (Decima, 1975).

At Site 376 the strontium content in gypsum is 1000 $\mathrm{ppm}$ to $1500 \mathrm{ppm}$. Gypsum which has precipitated with halite from evaporated seawater should have 2100 ppm-2300 ppm strontium (Usdowski, 1973). The low content of strontium in the Site 376 gypsum further confirms that they are not first-generation evaporites precipitated from evaporation of marine water, but are instead recycled deposits derived, at least in part, from the reworking of older deposits.

\section{Halite and Polyhalite From Site 374}

The bromine content of halite from Sample 22-3, 24-34 $\mathrm{cm}$, ranges from $114 \mathrm{ppm}$ to $218 \mathrm{ppm}$. The

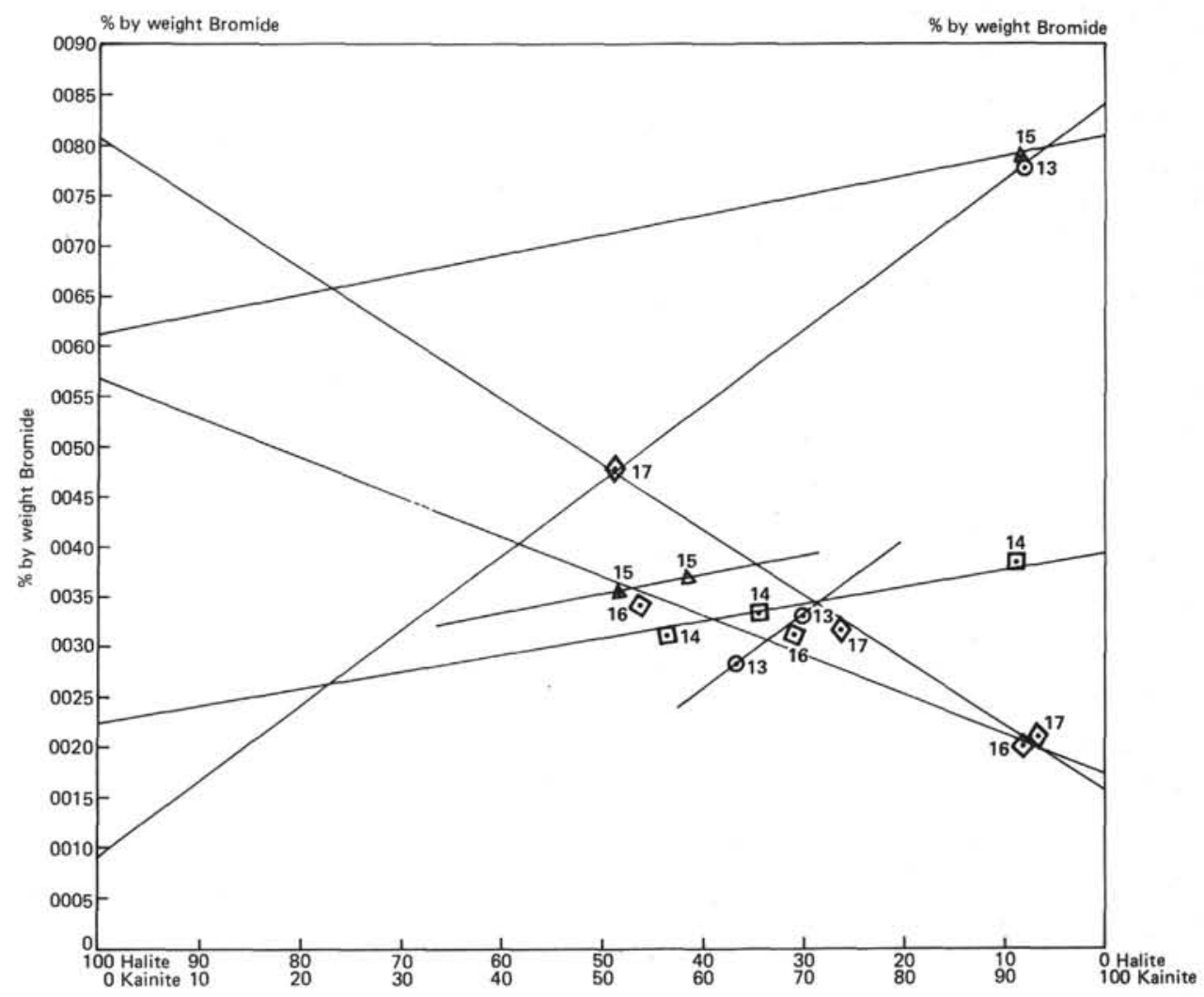

Figure 4. Calculation of bromine content in halite and kainite (see text for explanation). Samples are denoted by symbols of different shape. 
TABLE 6

Extrapolated Results of the Bromine Content in Halite and Kainite, Sample 374-22-3, 107-130 cm

\begin{tabular}{|c|c|c|c|}
\hline \multirow[b]{2}{*}{ Specimen } & \multicolumn{2}{|c|}{ Br contents ( $\%$ by wt) } & \multirow{2}{*}{$\begin{array}{c}\text { Weight } \% \text { nal } \\
\text { distribution } \\
\mathrm{Br}_{\text {halite }}: \mathrm{Br}_{\text {kainite }}\end{array}$} \\
\hline & Pure Halite & Pure Kainite & \\
\hline 13 & $(0.009)$ & 0.084 & $(1: 9.3)$ \\
\hline 14 & 0.0225 & 0.0398 & $1: 1.7$ \\
\hline 15 & $(0.0613)$ & 0.0805 & $1: 1.3$ \\
\hline 16 & $(0.057)$ & 0.0172 & $1: 0.3$ \\
\hline \multirow{2}{*}{17} & $(0.0805)$ & 0.01505 & $1: 0,2$ \\
\hline & & & $\begin{array}{c}\text { mean distribution } \\
1: 2.6\end{array}$ \\
\hline
\end{tabular}

values for halite in samples 4, 6, 8, 9 (178 ppm-219 $\mathrm{ppm}$ ) fall within the range of values for marine halite precipitated with polyhalite. However, the values for other samples (114 ppm-143 ppm) fall within the range of values for marine halite precipitated with anhydrite. Mineralogical association indicates that the halite in this core was precipitated with polyhalite. The brines probably were derived largely from the evaporation of seawater. The low bromine values for some samples may have been caused by mixing of seawater with some waters of continental origin.

The very abrupt changes of the bromine content in the halite is evidence against its deposition in a deep brine pool. The bromine profile for this core is similar to that for the halite at Site 124 (Leg 13), where the evidence is conclusive for the existence of a shallow brine pool during the time of salt deposition (Kuehn and Hsü, 1975). The depositional environment of immediately overlying sediments, which show signs of repeated desiccation (Garrison et al., this volume) further indicates that the brine lake was nearly evaporated dry at the time of salt deposition.

\section{Halite and Kainite From Site 374}

The rubidium content of the kainite in Sample 22-3, $107-130 \mathrm{~cm}$, is estimated to be about $8 \mathrm{ppm}$. This is considerably more, although still comparable, to the values obtained for the kainite in Sicily which range from $1 \mathrm{ppm}$ in kainite at San Cataldo (Barbieri and Penta, 1968) and to $2.7 \mathrm{ppm}$ in kainite at Montedoro (Kuehn, 1972). The cause of the rubidium enrichment is unknown.

In Core $374-22-3,107-130 \mathrm{~cm}$, the average bromine content of halite is somewhat greater than, and that of kainite is somewhat less than, that found in halite from land sequences (Table 7). The discrepancy is, however, slight and may be caused by a slight error in determining the ratio of $\mathrm{Br}_{\text {halite }} / \mathrm{Br}_{\text {kainite. }}$. The values are similar enough for us to conclude that halite and kainite at Site 374 are primary and that they were precipitated from evaporated seawater in a manner similar to the precipitation of primary potash salts of Sicily.
TABLE 7

Comparison of Bromine Content in Halite and in Kainite From Various Locations

\begin{tabular}{lcc}
\hline \multicolumn{1}{c}{ Location } & $\begin{array}{c}\mathrm{Br} \text { in } \\
\text { Halite (\%) }\end{array}$ & $\begin{array}{c}\mathrm{Br} \text { in } \\
\text { Kainite (\%) }\end{array}$ \\
\hline $\begin{array}{l}\text { DSDP Sample 374-22-3, 107-130 cm } \\
\text { (this paper) }\end{array}$ & 0.032 & 0.083 \\
$\begin{array}{c}\text { Mine Zolfo de Bosca/Caltanisetta } \\
\text { (Kuehn, 1968) }\end{array}$ & 0.029 & 0.11 \\
$\begin{array}{l}\text { San Cataldo } \\
\quad \text { (Barbieri and Penta, 1968) }\end{array}$ & - & 0.084 \\
$\begin{array}{l}\text { Montedoro } \\
\quad \text { Kuehn, 1972) }\end{array}$ & 0.106 & 0.097 \\
$\begin{array}{l}\text { Porto Empedocle } \\
\text { (Decima, 1975) }\end{array}$ & $0.02-0.025$ & - \\
\hline
\end{tabular}

The abrupt changes of the bromine content in halite and in kainite might be explained in several ways. Such a bromine profile is, however, consistent with our conclusion that the brine lake was rather shallow when the last salts were deposited at Site 374 .

\section{ACKNOWLEDGMENT}

The chemical analyses of the salts were made by $\mathrm{K}$. H. Ritter, first analyst of the Kali and Salz Company's Kaliforschungs-Institut, Hannover. We thank Mr. Ritter and express our great appreciation of his diligent and exact work.

\section{REFERENCES}

Barbieri, M and Penta, A., 1966. Osservazioni geochimiche sulla serie evaporitica miocenia die San Cataldo (Caltanisetta): Period. Mineral., v. 37, p. 777-804.

D'Ans, J. and Höfer, P. 1934. Untersürhüngen an Brom: Z. Angew. Chem., v. 47, p. 71-74.

Decima, A., 1975. Considerazione preliminari sulla distribuzione del bromo nella formazione Salina della Sicilia meridionale, preprint of an article to be published in the Prod., Messinian Seminar, Erice, Sicily, October 1975.

Hsü, K. J., Cita, M. B., and Ryan, W. B. F., 1972. Origin of the Mediterranean Evaporites. In Ryan, W. B. F., Hsü, K.

Kuehn, R., 1968. Der Einfluss mineralogisch-geochemischer Untersuchungen auf die Vorstellungen zur Bildung von Kalisalzlagerstätten: Ber. Deutsch. Ges. Geol. Wiss. B., Miner. Lagerstattënf., v. 13, p. 193-217.

J., et al., Initial Reports of the Deep Sea Drilling Project, Volume 13: Washington (U.S. Government Printing Office), p. 1023-1031.

, 1972. Zur Kenntnis der Rubidiumgehalte von Kalisalzen ozeanischer Salzlagerstätten nebst einigen lagerstättenkundlichen Ausdeutungen: Geol. Jahrb., v. 90 , p. $127-220$.

Kuehn, R. and Hsü, K. J., 1975. Bromine content of Mediterranean halite: Geology, v. 2, p. 213-216.

Kuehn, R. and Ritter, K. H., 1958. Der Kristallwassergehalt von Kainit und Löweit: Kali and Steinsalz, v. 2, p. 238239.

Usdowski, E., 1973. Das geochemische Verhalten des Strontiums bei der Genese and Diagenese von Ca-Karbonatund Ca-Sulfat-Mineralen: Contrib. Mineral. Petrol., v. 38, p. 177-195. 